Historic, Archive Document

Do not assume content reflects current scientific knowledge, policies, or practices. 



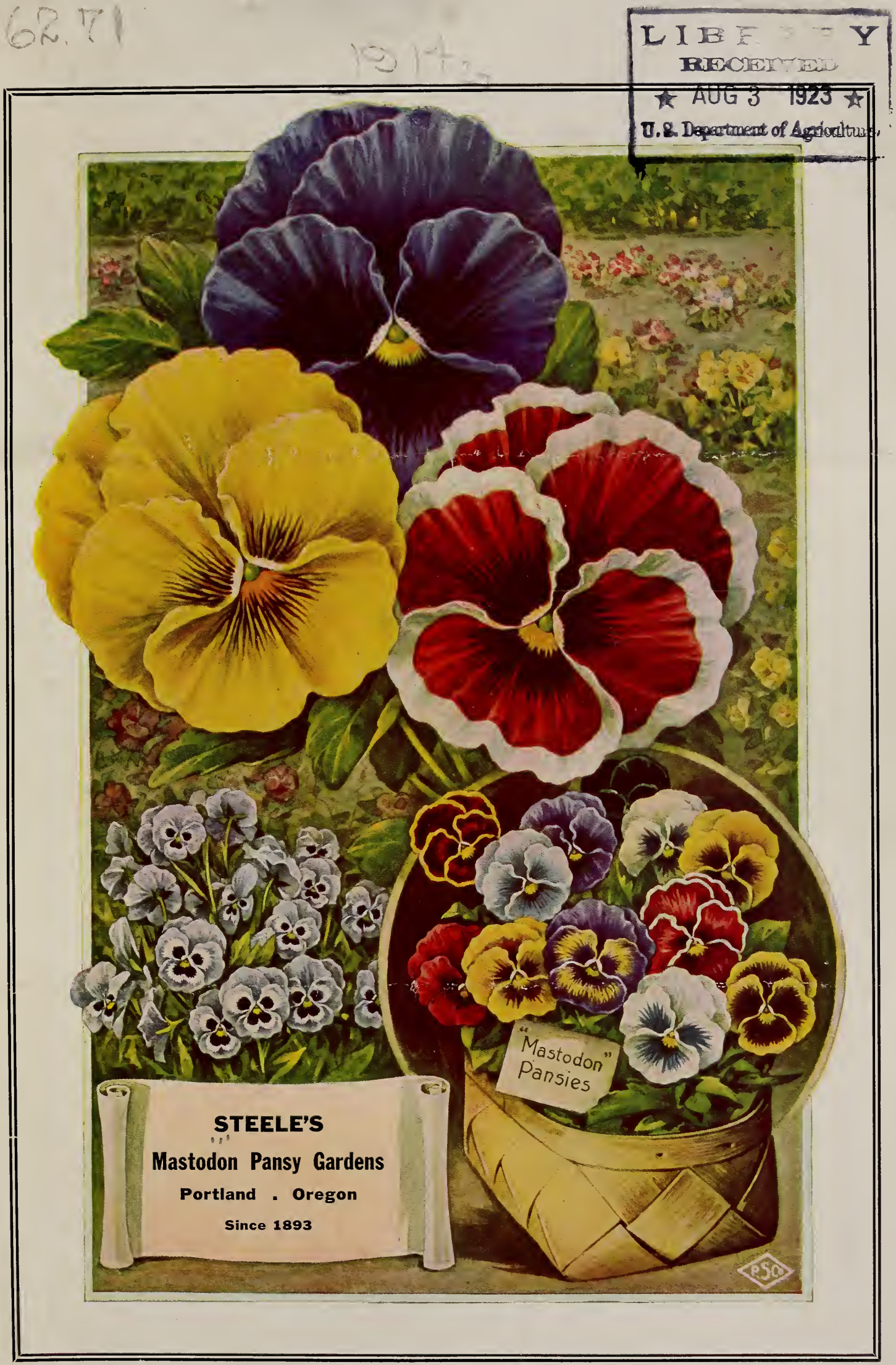




\section{Steele's Mastodon Pansy Gardens}

\section{OUR COLOR PLATE}

W

E want to impress you with the fact that all the pansies in this plate are reproductions of blooms unfolded in our gardens. If you will visit us any time between April first and October first you will see these, and tens of thousands more, in all their glory. Of course, this plate does not show actual size: as you will perceive when we say that the smallest pansy in the basket was over three inches in diameter.

\section{SOMETHING DIFFERENT, AND WHY.}

Superb pansies are not creatures of chance any more than chimes of bells just happen to be so. High-bred Pansies will never be cheap and plentiful for the same reason that blooded horses will never be purchased for a song. The methods employed to produce them are practically the same.

Mastodon is our name for a genuine American strain of Pansies originated by us, and comprising a marvelous number of new shades and varieties, as well as improved types from other lands. All are of excellent form, of the richest colors, and of great size-up to three and seven-eighths inches in diameter. Mastodon Pansies represent twenty years' of special and exclusive cultivation under our personal direction and constant supervision, and large sums expended in securing the finest stock grown hy specialists all over the world. Even United States embassies in foreign countries have been asked to assist us in the search for rare and beautiful kinds. Many experts from the Western and Eastern continents have visited our gardens and they are unanimous in the opinion that Mastodon Pansies are unique, and without an equal anywhere.

In building this strain we did not follow our fads and fancies, but we asked the public - the people who buy the plants in bloom - to select and anprove the finest for our seed beds, and we have bent our energies to improve the form and especially to increase the size.

\section{Are You Growing Pansies for Profit or for "Glory?"}

Suppose that with ordinary Pansies you get from twenty-five cents to fifty cents per dozen for blooming plants, and your beds only clean up from forty to sixty per cent of the entire crop-do you make any money? We think not. Here is our test of a strain of Pansies: How many plants are left at the end of the season? Our beds clean up ninety-five to ninety-nine per cent at the finish, with prices at fifty cents per dozen up to twenty-five cents apiece!

\section{Get This Under Your Hat.}

Ordinary Pansies are produced from seed grown in Europe. Pansies in that climate come into bloom about June first. Mastodon Pansy Seed is grown in Oregon and we begin marketing blooming plants in February. Therefore, when you sow Mastodon and ordinary seed at the same time, Mastodons bloom from two to six weeks earlier than the other. Again, Mastodons are all field grown stock, hence they are hardy and vigorous-"the survival of the fittest."

\section{Looking Backward.}

After these many years spent in the cultivation of pansies only, I hope our many friends and patrons, and you, dear friend and admirer of "the little stepmothers," will pardon me if I say a word or two of the days that are gone by, before I speak upon the subject tha is nearest my heart, and that I trust may be nearest to yours - the pleasure and profit in the cultivation of pansies.

I began growing pansies the same as I began growing other flowers, fruits, and everything else that would grow in a garden. But nothing would grow like the pansies. Thus it was that these upturned faces aroused my interest. I worked with them by day, and I carried my lantern among them by night. At first my friends and neighbors surveyed my conduct with curiosity; then with wonder, and finally they seemed to see the image of a man controlled by an illusioned, vagrant mind. "Why don't you raise potatoes?" said one. "Grow something to eat," advised another. Little was the hope abiding in me that there was any bread and butter in growing pansies. But my faith was constant and strong that I could build up a magnificent strain of pansies such as the world had never seen. That if I could accomplish this, something would be done worth while.

I did not know the task I had set myself to do, the difficulties to meet, the obstacles to overcome. The years went by, and there came by slow degrees to those who watched and waited, the knowledge of the scope and purpose of my plans. Thus it was that this industry came to be. Speaking for myself and my associates, let me say: Our hopes are with us; our ambitions in the pansy world are boundless. We know that the number of our friends and patrons is legion, and that we shall have their strong support. We know that our new patrons of the coming year will be many. We know that you will be with us on the merits of Mastodon Pansies, now or by and bye.

(Signed) 


\section{THE MADAME STEELE (New).}

The only new self pansy of this century. It is a genuine royal purple self, of fine form, great substance, and enormous size. We have never seen a basket of pansies that could compare in beauty and richness of color with the Madame Steele. The best pansy on earth for the best people on eartha true "Elk's Purple." See Page

\section{REPORTS.}

We take a personal interest in all our patrons, and we want you to report your successes, and if you haven't won out on Pansies, let us know about that, too. It is up to us to see that every one who grows Mastodon Pansies shall share our success, and if you will give us a chance we will make good.

\section{MR. GROWER, ITS UP TO YOU.}

All the leading seed and plant stores, fiorists and many other dealers in the Northwest handle Mastodon blooming pansy plants every season. They also handle other pansies. But they get from two to four times the price for Mastodon Pansies that they get for ordinary pansies. Even at these prices they are unable to get a sufficient quantity of Mastodon Pansies to supply the demand.

\section{THE MOST OF THE BEST FOR THE LEAST.}

Now, if you will study the classfied columns of the trade journals, you will find that notwithstanding the unquestioned superiority of Mastodon Pansies, they cost you no more and in some cases less than other pansies. If you contract with us to grow your plants, they will be the cheapest of nearly all. See "New and Special." There are excellent economic reasons why we can make these prices which space forbids us to explain. It is chiefly because of the magnitude of the business, and the undivided attention we give to this one specialty. We guarantee no regrets when you grow Mastodon Pansies, and we want to book your trial order on that basis. Give us a chance. See "New and Special."

\section{THE AEROPLANE OR THE TOBOGGAN, WHICH?}

In this, the twentieth year of our exclusive cultivation of pansies we wish to express our sincerest thanks to our many purchasers of plants over all North America, and to those who bought seed throughout the world. Every month last year was a record breaker. Single orders for seed approached close to three figures, and we sold more seedlings in the two months of September and October than we ever sold before in any two years.

We numbered among our new patrons some of the largest and finest cemeteries and public and private parks on the Western continent; also pansy specialists, educational institutions, commercial growers, who handle up to a hundred thousand or more pansy plants every year, seedsmen and florists, as well as those who supply the local trade of city or town. We explain this marvelous record in three ways.

1. Our liberal policy to the trade. We allow no competitor to outdo us in this respect. We absolutely satisfy every customer. Any patron can tell you how we do it. Let us refer you to some of them in your own State. Write us.

2 Every visitor to our gardens becomes a booster for Mastodon Pansies. Every buyer from Maine to

\section{UNSOLICITED TESTIMONIALS}

You have great advantages in your climate for raising pansies, and I am thoroughly satisfied that your seed will go with a rush.

\section{LUTHER BURBANK.}

I am delighted with the beauty of your pansies. I have grown pansies every year since 1865 , and have bought seed from all parts of the U. S. F. P. AVERY

$I$ received your pansy plants and at once planted them in cold frames, and would you believe it? I shall not lose more than one or two.

\section{Chillicothe, O.}

I got some pansy plants from you last Winter and they were surely lovely. They were admired by thousands.

H. J. V.

Pasadena, Cal.

Your extra package of 300 pansy plants rec'd and planted. Many thanks for making good. Your plants are fine.

W. $\mathbf{P}$.

Lee's Summit, Mo.

A friend of ours who visited your gardens wrote us about your beautiful pansies, and sent us a sample bloom. Enclosed find $\$ 1.00$ for seed.

H. E. M.

Letcher, S. D.

Please book my order for 2000 Mastodon Mixed, and 100 Madame Steele. The blooming plants were the best ever seen here.

T. M. M.

St. Joseph, Mo.

Enclosed find $\mathrm{m}$. o. for seed. Your seed last year was A No. 1, and the results very gratifying. G. G. Berkeley Cal.

I wish to place an order with you for 2500 Mastodon Mixed. The pansies I got from you last year were very fine. I could have sold more if I had them

S. W.

Alameda, Cal.

I received the blooming plants which I ordered from you in first class condition. They looked as though they had been dug from the ground an hour before I got them, and were the finest I have ever seen.

J. E. S.

Los Angeles, Cal.

M. O. enclosed. Please send us another shipment of your pansy plants. Your other shipment has fully come up to our expectations. Every one who sees them admires them. They are wonderfully beautiful and large.

$$
\text { Las Palmas Greenhouses, Cal. }
$$

Send us prices of plants in bloom. Seedlings received doing fine. Largest flowers and best colors we ever had. Going fast. Am afraid we are going to run out.

Twin Falls Floral Co.

M. O. enclosed for another shipment of Mastodon pansy plants. I bought a thousand of you last year, and every one declared them the finest ever seen. They were superb. They reached me in fine shape.

M. E. S.

Hutchinson, Kan.

The 2500 pansy plants came to hand O. K. and were very satisfactory. Check enclosed for 2500 more.

$$
\text { W. S. } \mathrm{H} \text {. }
$$

San Antonio, Texas.

Please mail us $\$ 5$ worth of your Mastodon Mixed seed. We tried out you r strain last year and found them fine- "things of beauty and a joy forever." Broadway Dept. Store, Floral Dept. Los Angeles, Cal. 


\section{THE AEROPLANE OR TOBOGGAN, WHICH? (Continued)}

California is an enthusiast about Mastodon Pansies. How do we know this! See unsolicited testimonials. Again, in many instances, where we had one customer two years ago in a city or town we have now from two to seven in the same place.. Where we placed orders two years ago there came last year in nearly all cases, repeat orders two or ten times as large. We most cheerfully concede that a very large measure of our success has come from the advertising of Mastodon Pansies by growers of Mastodon Pansies.

3. Its the pansies - the unquestioned superiority of Mastodon Pansies, and the premier quality of the plants, grown on thinly sown beds in fertile, highly fertilized soil under the open sun in the open field during the entire year. Twenty years ago we began the exclusive cultivation of pansies with one certain and definite aim in view. Our plan was to take the finest strains of pansies in existence, and by methods of breeding and selection to create a new variety that would retain all the qualities a perfect pansy should have, and to eliminate all the deficiencies that still marred the beauty of the blooms. Thus to realize our ideal by producing pansies gigantic in size, perfect in form, brilliant in color, and rich and velvety in substance. We have ever kept in mind this ideal pansy. We have never lost our aim. We have never faltered in our purpose. This is why Mastodon Pansies are better than other pansies. This is why Mastodon Pansies are better now than in the past. This is why Mastodon Pansies will be better in the future than they are now. We are not going down on the toboggan, but we are soaring upward with the aeroplane!

To meet the increasing demand for seeds and plants it has become necessary to greatly enlarge our facilities for production. We therefore take great pleasure in announcing that we have acquired a farm for this purpose, the same being within the boundary and near the the business center of this great city. It will be known as Steele's Mastodon Pansy Gardens as before, and will be the largest establishment for the exclusive cultivation of pansies in the Western world. There we shall be able to carry on our operations on a scale that the excellence of Mastodon Pansies will require. There we shall have ample room and opportunity for our work, which will be a pleasure to us, and which we are certain will be of profit to our patrons. Come and see us.

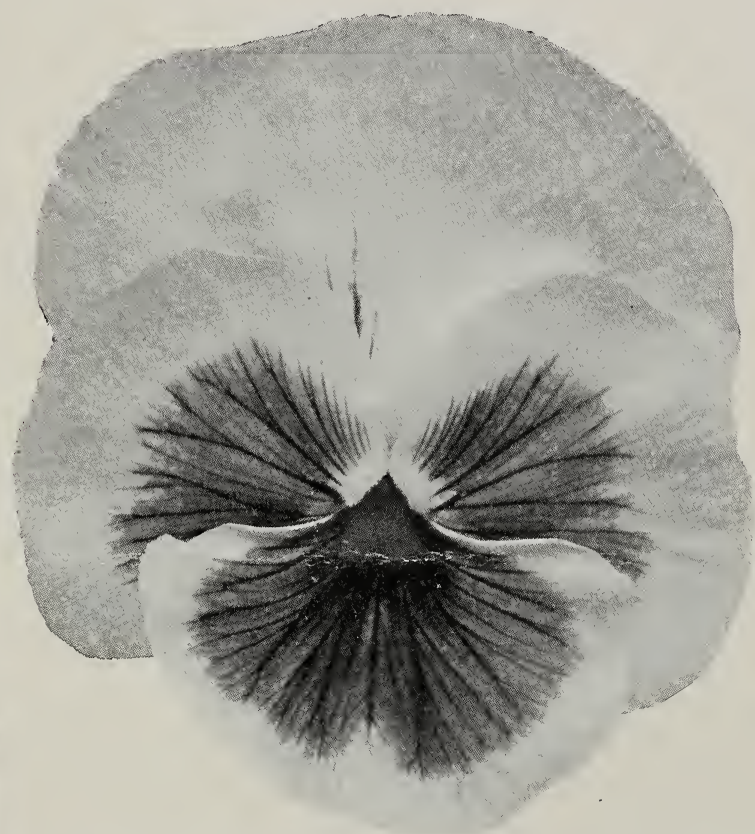

PESTS.

Red spider is the worst enemy of the pansy, though it usually does not appear till mid-Summer. We use a strong spray of water daily or every two days as occasion requires. The same treatment will dispose of green aphis. For black aphis use one part nicoticide to fifty parts water, and apply with spray pump. To kill worms or anything that eats foliage: To $11 / 2$ gallons soapy, warm water add teaspoonful paris green and apply with whisk broom or spray pump. For slugs lay boards in paths between beds. Turn boards over once a week, and destroy with salt or lime. After a month or two there will be "nothing doing" in the slug family.

\section{DAMPING OFF.}

This is about the only disease that attacks pansies. Use one tablespoonful nitrate of soda to one gallon of water, and moisten soil with solution. Repeat every two days for a week or so. The best way to fight disease is to prevent it. It is most likely to attack seedlings. The usual cause appears to be lack of humus in the soil, although it may be from lack of air and sun, bad drainage, or plants too thickly sown. One plant to the square inch is the maximum capacity of a seedling bed; 100 plants to the square foot is better. It has never appeared in beds prepared as described in "Cultivation" and "Germination" in this catalog. See page eight.

\section{WATERING.}

In a climate where the days are warm, and the nights cool, water in the morning only. In climates where the nights are warm it may be safe to water at night. Let water run from butt of hose, so that it will soak in and do not water foliage at night. See cultivation. 


\section{Seedlings}

\section{In Stock from September First to May First \\ WHOLESALE PRICES NET}

\section{NEW AND SPECIAL.}

We will grow your plants under contract, at a price that will make it a waste of time for you to grow them yourself. Write us before July 15th for estimate, and state number of plants you will reed. Remember we guarantee perfect order delivery to any part of North America with railroad communication.

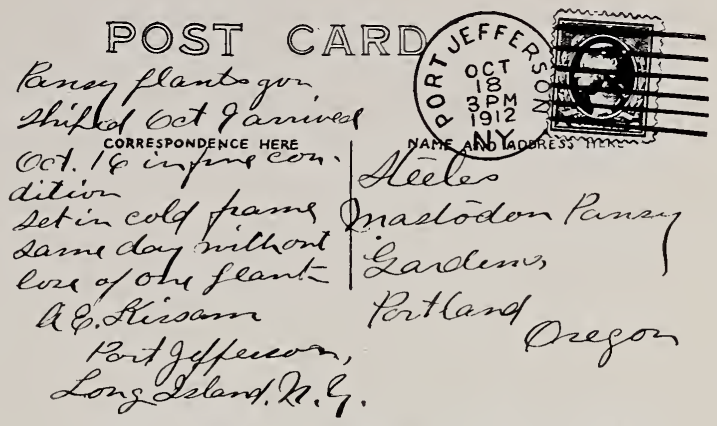

FROM OCEAN TO OCEAN IN PERFECT ORDER

\section{Prices of Seedlings}

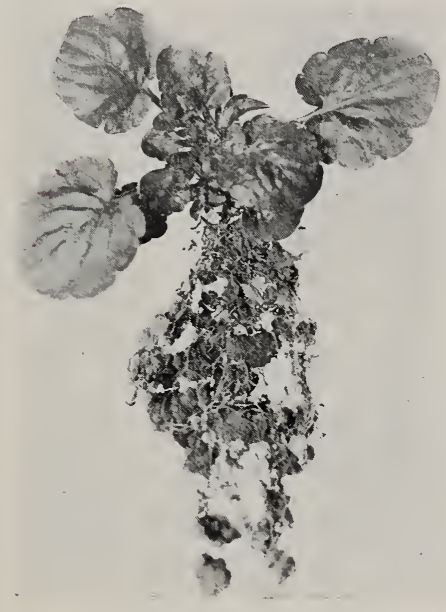

SEEDLING, FIVE LEAVES

Large selected, six to eight leaves, Mastodon Mixed, or any separate color, except Madame Steele, per 100,75c; per $500, \$ 2.75$; per $1000, \$ 5.00$; per $5000, \$ 23.50$; per 10,000 , $\$ 44.00$; per $20,000, \$ 85.00$.

Standard size selected, four to six leaves, per $100,50 \mathrm{c}$; per 500, $\$ 1.80$; per $1000, \$ 3.00$; per $2500, \$ 7.00$; per 5000 , $\$ 13.50$; per $10,000, \$ 26.00$; per $20,000, \$ 50.00$.

Orders for more than 5000 will be shipped in two lots and at our expense, if consignee so desires. Orders for 10,000 to 20,000 in lots of 5000 or more at our expense. Orders of 5000 or less in two shipments add 50 cents for extra express charges.

Steele's Private Stock, Mastodon Mixed, per 100,75c; per $500, \$ 2.25$; per $1000, \$ 4.00$ straight. Single orders limited to 5000. See page 7 .

Madame Steele, stanrard size selected, prices same as large selected Mastodon Mixed. Single orders limited to 1000 .

Extra large reset plants, before January first only. Price per $100, \$ 2.00$; per $500, \$ 9.00$; per $1000, \$ 17.00$. Separate colors same price. Madame Steele and Private Stock, add $25 \%$.

\section{ALL ARE PREPAID.}

Terms: Cash with order, or satisfactory reference required. Those who send cash with order, and those who leave selections to us, will be treated with the greatest liberality. 


\section{Re-Set Plants \\ In Stock from February First to July First}

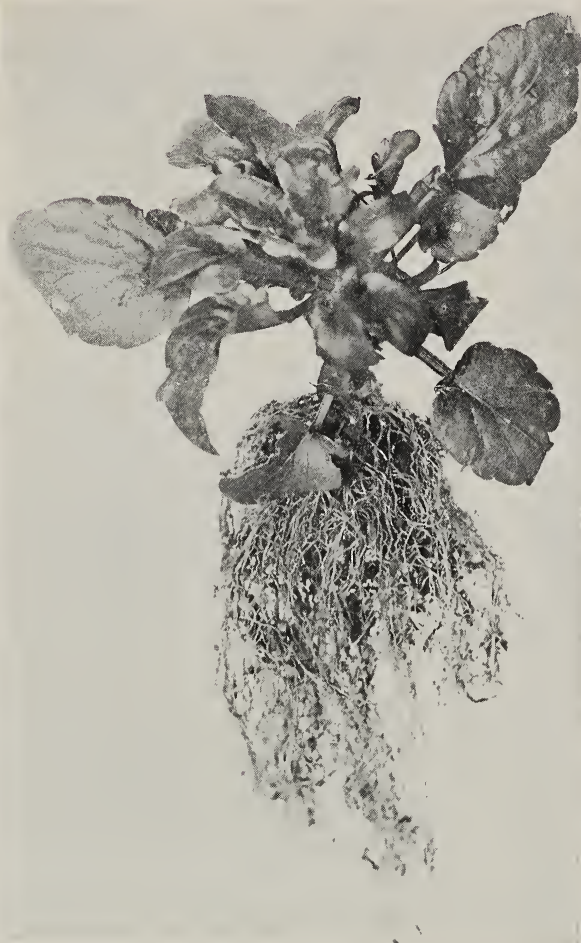

OC'TOBER RE-SET--PHOTO IN JANUARY
Our specialty is blooming plants in baskets, and we offer the same stock from the same beds that supply our blooming plants.

Re-set in September and October, will bloom in March and April. Per 100, \$2.50; per 1000, $\$ 22.50$.

Re-set in November, will bloom in April and May. Per 100, \$2.25; per 1000, $\$ 20$.

Transplanting will not check growth at all. Large, re-set plants in full bloom are offered to the trade in lots of twelve dozen or more, in twelve shades of colors, each separate, securely boxed but not in baskets, for shipment after April first.

Large size blooms, per 100, $\$ 3.25$, straight. Very large size blooms, special shades and colors, $\$ 3.50$ per 100 straight. Mammoth blooms, very large size plants-individual plants often bearing two to eight blooms, $\$ 4.00$ per 100 straight. All express prepaid.

All plants are field grown and carefully selected. Separate colors, prices same. Private stock, add 25 cents per 100 straight. Madame Steele, add 50 cents per 100 straight.

As to preparing beds for re-set stock until ready for market, see Cultivation. Of course, re-set plants require more room, and that can be supplied by setting plants 4 or 5 inches apart in the row

\section{Blooming Plants in Baskets}

\section{In Stock March First to July First}

We are oiiginators of pansies in baskets. Our pansies are packed one dozen or more in a basket. Our baskets are made by our own basket maker of the finest material obtainable, are very artistic, and are without an equal in their class. Each plant in full bloom is carefully lifted with a more than generous amount of soil clinging to the roots, so that when transplanted, it will grow at once and continue to bear flowers, under proper care, in this climate, during the entire year. Plants are packed in baskets, with all blooms facing one way, and artistically arranged to produce a blending of colors.

It is impossible to describe the regal splendor of a basket of these huge blooms. Those who see them marvel that it is possible to produce such flowers.

In all our experience of eighteen years shipping pansies in baskets we have never had one complaint as to quality or price.

Large size blooms, per basket, 40 cents.

Very large size blooms, special shades and colors, per basket, 50 cents.

Extra large size blooms, selected, fancy shades and colors, per basket, 65 cents.

Gigantic blooms, exhibition flowers, selected plants (see color plate), per basket, $\$ 1.00$ to $\$ 1.50$.

Special orders for on€ or more separate shades or colors, per basket, 65 cents to $\$ 1.00$.

Madame Steele, royal purple (new), per basket, 75 cents to $\$ 1.50$. For prices of blooming plants not packed in baskets, see RE-SET PLANTS. All prepaid. Less than eight baskets add fifty cents for prepay exrress charges.

No charges for packing and boxing. We guarantee perfect order delivery. We ship by mail and express only. All shipments are prepaid. We guarantee all our plants and seeds true to name and of the very best quality, but of course, we cannot guarantee a crop. Our seed is all fresh, new stock, but we cannot guarantee that it will germinate even though we sow it ourselves.

Terms: Cash with order, or satisfactory reference required. Those who send cash with order, and those who leave selections to us, will be treated with the greatest liberality. 


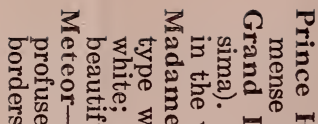

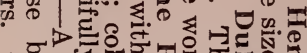
윤ㄷำ

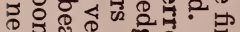

०

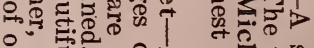

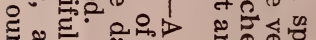

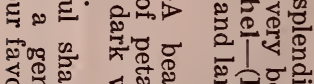

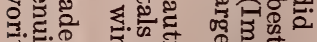

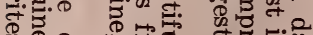
ญ๐

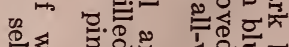

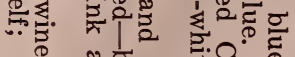
夷 ธี้

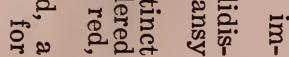

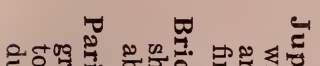

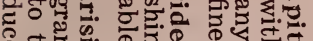
( 55 ว. 席先 त्ञ 국 등

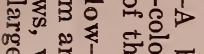
\& $\leq 5$

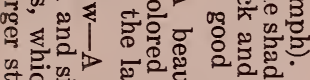

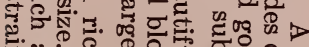

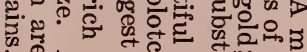

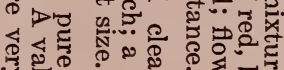

यढ

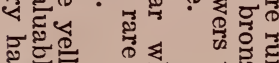

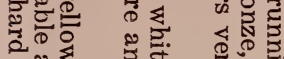

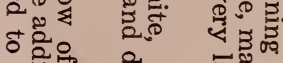

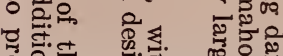

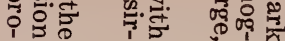

क

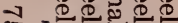
जात्र

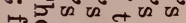

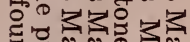

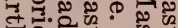
एक

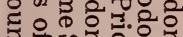

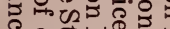

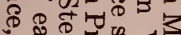

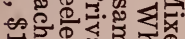
iा대유 대유

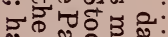

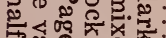

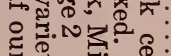

క

हึ: ह त्व:

: : :

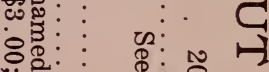

- क्

T

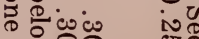

है

ถุ้

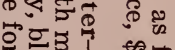

क

융요 뎐 용용

D

(

I)

$\sum$

范 प

吕

요

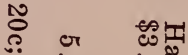

‥ 8 귬

究 0 ब

호

융 융 



\section{The Seed}

The growing of Mastodon Pansy Seed is a branch of our business that is given my personal attention daily, from the time the plants are selected in bloom-about one out of a hundred in the field-to the time when the seed is sealed in the package, so that I know positively the premier quality of every package, and you get exactly the same kind of seed that I sow and grow. We offer a few varieties grown for us by European specialists, but not labeled Mastodon Pansies, that we have tried out and found to be excellent. These are among the very best of more than two hundred strains we have tested. We do not use the word "giant" when referring to size, because it has come to mean nothing in that sense, many co-called "giant" strains producing blooms, as you know, not as large as a silver quarter.

Before you order seed read about "Seedlings."

\section{STEELE'S PRIVATE STOCK.}

Frequent calls from our patrons for something extra fine-something even better than our Mastodon Mixed, and the acquisition of a small farm for pansies exclusively, has prompted us to place upon the market a limited quantity of our "Private Stock."

Our plan in upbuilding Mastodon Pansies is and was to make a careful selection of a small percentage of the plants in the field-the finest of course-for our seed beds. The rule was established twenty years ago never under any circumstances to allow a seed plant to leave the gardens. It is a rule that is never broken, as our visitors know.

Then, to select from among the plants bearing the largest, most beautiful and most perfect flowers, and gather from these plants the seed we sow to select plants from the coming year. Hence, the name, Private Stock.

THE SEED.

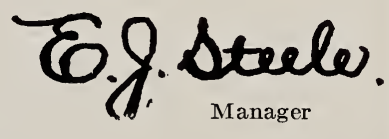

The strain originated by us and named Mastodon, runs a trifle light in colors, and includes white with dark center, dark blue center and light blue center, pure white, black, lavender, violet, blue, bronze (new), royal purple (new), rose, cerise red, red with silver rim, mahogany, yellow (new), wine colored, red and gold, lavender and gold, with a dozen or more varieties in each color in size, measuring up to three and seven-eighths inches in diameter. See colorplate.

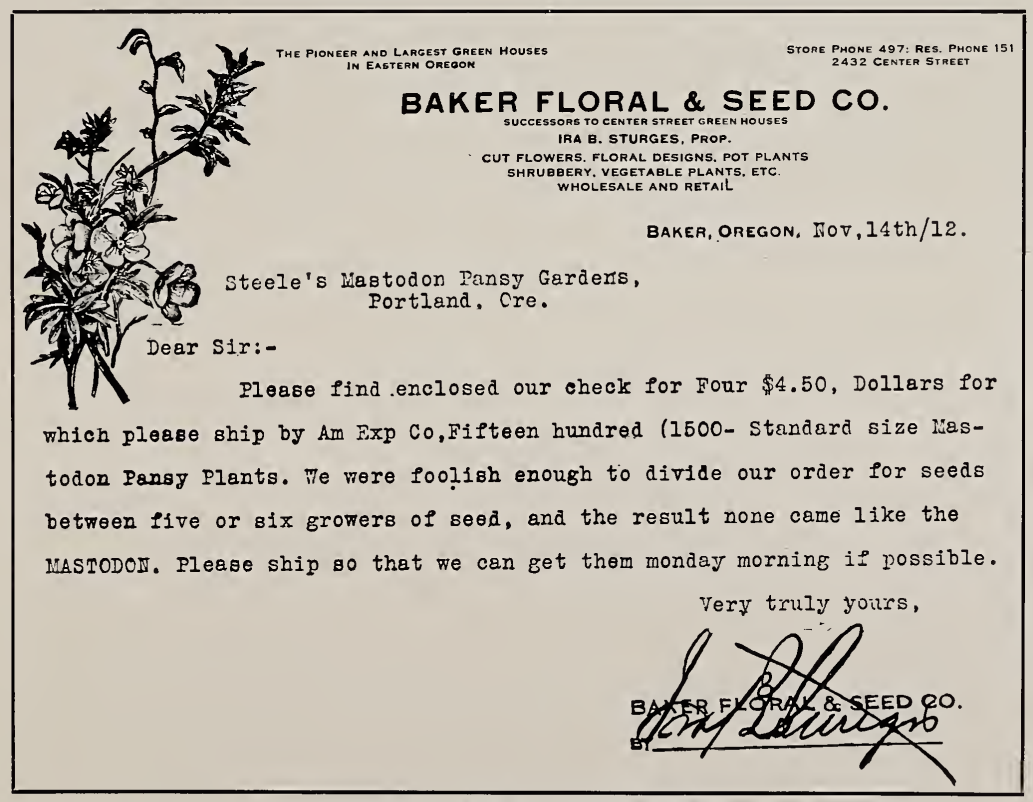

NOTHING LIKE MASTODON SEED 


\title{
The Seed--Continued
}

\author{
PRICES, NET.
}

\begin{tabular}{|c|c|c|c|c|c|}
\hline & $\begin{array}{l}200 \text { Seeds } \\
\ldots \$ 0.25\end{array}$ & $\begin{array}{c}\text { 1-12 Oz. } \\
\$ 1.00\end{array}$ & $\begin{array}{c}\text { Quarter Oz. } \\
\$ 2.50\end{array}$ & $\begin{array}{l}\text { Half Oz. } \\
\$ 4.75\end{array}$ & $\begin{array}{c}\text { Oz. } \\
\$ 9.00\end{array}$ \\
\hline $\begin{array}{l}\text { Stock, Mixed } \\
\text { ee Page } 2 \ldots\end{array}$ & $\begin{array}{l}.50 \\
.50\end{array}$ & $\begin{array}{l}1.50 \\
1.50\end{array}$ & 4.00 & 7.50 & 14.00 \\
\hline
\end{tabular}

The prices of each of varifties named below is as follows: 200 seeds, 20c, eighth ounce, $\$ 1.00$, fourth ounce, $\$ 1.75$, half ounce, $\$ 3.25$, one ounce, $\$ 6.00$.

Prince Henry-A splendid dark blue of immense size. The very best in blue.

Grand Duke Michel-(Improved Candidissima). The finest and largest all-white pansy in the world.

Madame Perret-A beautiful and distinct type with edges of petals frilled-bordered white; colors are dark wine, pink and red, beautifully veined.

Meteor-A beautiful shade of wine red, a profuse bloomer, a genuine self; fine for borders. One of our favorites.
Jupiter-(Triumph). A mixture running dark with many fine shades of red, bronze, mahogany, blue, black and gold; flowers very large, fine form and good substance.

Bridesmaid-A beautiful clear white, with shining rose-colored biotch; a rare and desirable pansy of the largest size.

Parisian Yellow-A rich pure yellow of the grandest form and size. A valuable addition to the yellows, which are very hard to produce in the larger strains.

It will pay you to read inside pages carefully. Prices for seed are NET.

\section{GERMINATING SEED.}

If your soil is not of the quality of first class potting soil prepare your bed for sowing as follows: (1) Your ground being perfectly clean and free of weeds and trash, pulverize the soil to a depth of six or more inches. (2) on the level surface spread evenly a layer of pulverized manure, barnyard scrapings preferred, to a depth of at least one inch. (3) Overlay manure with half inch of the best soil you have thoroughly pulverized. (4) Roll or rake down and tramp surface true and smooth. (5) Use the hose freely and soak down the bed several inches. (6) Sow your seed in drills or broadcast-we sow broadcast. (7) Cover as lightly as possible with your best soil or sand. Sand is best. (8) Use light spray of water to moisten surface. (9) Allowing plenty of ventilation, keep your beds moist, quite moist, but not soaking wet until plants come up.

We moisten our beds in the morning only, and use light canvas to retain moisture during the day, removing same at night. As soon as plants begin to come through freely we remove canvas permanently, and sift top of beds with a thin layer of barnyard scrapings.

Never allow your beds to become dry. Any dryness after seeds sprout is absolutely fatal. These directions are for sowing in the open field, but will apply when using flats or cold frames. We use 60 to 75 square feet to sow an ounce of seed. We estimate five to eight thousand plants per ounce. We have reports as high as eleven thousand per ounce. One grower reports 1200 plants from 1-12 ounce.

\section{GULTIVATION.}

Too much cultivation and preparation of the soil before making your beds for seedlings or re-set plants is impossible. Too little cultivation and preparation is common and almost fatal to any degree of success. Excellent drainage is essential. For re-sets the soil should be broken up to a depth of ten to twelve inches and thoroughly pulverized to a depth of six to eight inches. The ground should be clean and free of all trash and weeds. If soil is deficient in humus mix in about two inches of wels rotted manure. Don't be afraid of weeds in the manure. The weed seed is in the soil. Of course they grow when you fertilize the soil.

For re-set plants make your beds four to five feet wide, and line them up so that the paths between the beds will afford drainage. In a rainy climate it's a good plan to raise your beds by making your paths deep. Cover beds with a mulching of dairy yard or stock yard scrapings, or any well rotted, pulverized manure to a depth of about $11 / 2$ inches. Set your seedlings deeply, and in rows across the bed seven to eight inches apart so that you can use the hoe. For marketing purposes set plants $2 \frac{1}{2}$ to 3 inches apart in the row. For display beds double space in the row. Don't forget to use the hoe. Never allow top of soil to become packed. After a rain or after watering beds, use the hoe. Plants get more nourishment from the air than they do from the soil. Keep the pores open. Use the hoe! But don't hoe deep - cultivate surface only. Keep away from shade of trees and buildings as much as possible. Pansies will grow anywhere, but believe us, they are worshippers of the sun.

Our grandest flowers bloom in the open field.

Concerning Pests, Damping Off and Watering, see pape four. 